\title{
Industrial Production and Non-oil Export: Assessing the Long-run Implication on Economic Growth in Nigeria
}

\author{
Emmanuel S. Akpan \\ Department of Banking and Finance \\ University of Calabar, Nigeria \\ E-mail: Bushdukakis07@yahoo.com \\ Hodo B. Riman (Corresponding author) \\ Department of Banking and Finance \\ University of Calabar, Nigeria \\ E-mail: Horim105@yahoo.com \\ Joe Duke II \\ Department of Business Management \\ University of Calabar, Nigeria \\ E-mail: JoedukeII@yahoo.com \\ Helen Walter Mboto \\ Department of Banking and Finance \\ University of Calabar, Nigeria \\ E-mail: helenwalter31@yahoo.com
}

Received: August 28, 2011

doi:10.5539/ijef.v4n2p252
Accepted: September 13, $2011 \quad$ Published: February 1, 2012

URL: http://dx.doi.org/10.5539/ijef.v4n2p252

\begin{abstract}
The aim of this paper is to identify the role industrial sector plays in driving the GDP of Nigeria. The paper further seeks to predict the long-run behavioral relationship between industrial production, non-oil exports and economic growth in Nigeria using data from 1970 - 2007. Vector Error Correction Mechanism (VECM) was utilized to establish the co-integrating relationship between industrial production, non-oil exports and GDP. The paper reveals the existence of a positive and significant uni-directional relationship that runs from industrial production to non-oil exports. It was further evident in the study that the current policies on industrial production in Nigerian do not sufficiently encourage non-oil export. The paper therefore predicts an imminent collapse of the Nigerian manufacturing industries in the nearest future if immediate remedial measures are not quickly taken to strengthen the ailing industries. The paper among other things encourages the government to strengthen the legislative and supervisory framework of the Agricultural Credit Guarantee Scheme in Nigeria.
\end{abstract}

Keywords: Structural Adjustment Programme, Industrial Production, Non-oil export, Economic growth, Co-integration

\section{Introduction}

Nigeria over the years had been on the path of pursuing the quest to become one of the most industrialized nations in the world. Successive administrations had evolved several policies geared towards achieving this dream. The industrial sector had particularly witnessed dozens of promotional incentives, paradoxically; there appear to exist an inverse relationship between the number and legerdemain of such incentives and actual performance (Soludo et al, 2003) 
Available result indicates that in 1970, the contribution of industrial production to the nations GDP was 17.27 percent, manufacturing sub-sector contribution to GDP was 7.16 percent. Within the same year the contribution of non-oil export to the nations GDP was 7.11 percent while agriculture, which was then the bane of the economy, contributed 48.7 percent to the nation's gross domestic product. Everything seems right for the nation until crude oil was discovered in the early 70's. The focus and attention of the government was shifted to crude oil production as it was found to generate massive revenue for the country. Development in other sector took a summersault, industrial and agriculture production began to decrease as most of the workers who were involved in agrarian farming were found to migrate from rural to urban cities in search of white collar jobs. The result of this gradual resettlement shift was that in 1975 , the contribution of industrial production to GDP though slightly increased to 27.8 percent, manufacturing sub-sector, non-oil export, and agriculture accounted for merely 5.45, 1.6 and 20.38 percent contribution to GDP respectively. From this period onwards the nation began to witness a retarded growth in her GDP

In 1986, structural adjustment programme (SAP) was introduced by Ibrahim Babangida military administration to steer the economy back on path of development. Several policies were introduced to liberalize the economy and encourage export initiatives from local manufacturers, increase the consumption of locally produced goods, strengthen ailing industries and improve investment in agriculture by local farmers.

Unimpressively, several years after SAP policies were introduced, the nation was still way behind ripping the dividend of the policies so introduced. This was evident in the fact that the contribution of industrial production to GDP though increased from 31.04 percent in 1988 to 43.36 percent in 1995, this improvement was not observed among manufacturing sub-sector, non-oil export and agriculture whose contribution to GDP rather reduced from 10.57 percent to 7.44 percent, 1.86 percent to 1.14 percent and 36.3 percent to 30.5 percent respectively within the same period.

Despite all the policies so far introduced to improve industrial performance in Nigeria the country's GDP is still observed to be on the downward trend. It is however sad to observe that the contribution of industrial production to GDP rather than improve fell from 45.83 percent in 1995 to 41.53 percent in 2005 . The contribution of manufacturing sub-sector and non-oil export also reduced from 7.44 and 1.14 percent in 1995 to 2.89 and 0.7 percent in 2005 respectively. Adejugbe (1980) in a reaction to the poor performance of the sector stated that Nigeria industrial policies, objectives, and strategies were often subject to modifications, neglect or even total abandonment. He further opined that industrial policies and practice in Nigeria were pursued on ad-hoc basis and in a most uncoordinated manner. Thus, such situation can never promote an unequivocal growth in the country's GDP

Questions are rift as to why the industrial sector in Nigeria has not responded correspondingly to the numerous policies and funding so far expended on the sector. Does the industrial sector in Nigeria drive the country's GDP? And finally, what future does it hold for the country if the trend in dismal performance of manufacturing production continues unabated? These are the questions this research work seeks to address. This study is significant in the fact that, though studies abound on the contribution of exports to economic growth in Nigeria, this work to our knowledge is the first to study the co-integrating relationship between industrial production, non-oil exports and GDP in Nigeria. In attempting to answer the questions enunciated above the paper shall employ the Vector Error Correction Mechanism (VECM) to find the long-run relationship between industrial production, non-oil export and economic growth in Nigeria.

\section{Literature Review}

The industrial sector in Nigeria had continued to witness retarded growth since after the introduction of the Structural Adjustment Programme (SAP) introduced in 1986.

Unimpressively, the highest contribution of industrial sector to the nations GDP was noticed in 1995. Within that year the sectors contribution to GDP stood at 45.83 percent, while manufacturing sub-sector and non-oil export contribution to GDP was 7.44 and 1.14 percent respectively. Ikeze, Soludo and Elekwa (2001) observed that industrialization in Nigeria ascended during the oil boom era (1973-81, with manufacturing share of GDP reaching 11 percent) this performance was not however sustained as the sector experienced abrupt decline to five percent in 2000 . The industrial sector had failed to record appreciable improvement after then.

What could have been responsible for this dismal performance noticed in the industrial sector in Nigeria? In an attempt to answer this question, Adejugbe (1980) responded that Nigeria industrial policies, objectives, and strategies are often subject to modifications, neglect or even total abandonment. He further opined that industrial policies and practice in Nigeria are pursued on ad-hoc basis and in a most uncoordinated manner. This according to Adejugbe partly explains the reason for the concentration of Nigeria's few industries in major cities like Lagos, Kano, Ibadan, and Port Harcourt. 
The poor performance of the sector had also been attributed by other researchers to poor electricity supply situation in the country. Adeniran ( 2005 ) and Onyeonoru (2003) in their research observed a unidirectional causality that runs from GDP to Electricity consumption in Nigeria. In their separate work, they both observed that electricity production in Nigeria was sub-optimal and below the installed capacity utilization. They concluded their research by adding that sufficient electricity production was necessary for increasing industrial production in Nigeria.

Enang (2010) investigated the joint interaction between industrialization, electricity supply and economic growth in Nigeria within the framework of auto-regressive distributed lag (ARDL) bounds proposed by Presaran et al (2001). The paper found a feed back causality between GDP and Electricity supply. However, only a unidirectional relationship was observed between capital employed and GDP. The research finally confirmed that electricity supply, technology and capital employed were necessary for industrial and GDP growth in Nigeria.

Ajayi (2007) in describing the industrial trend in Nigeria observed that there is no significant relationship between the volume of production subcontracting and the size and structural characteristics of contracting firms. He observed that industrial production subcontractors were concentrated in Lagos, Ikorodu, Sagamu and Ibadan in the Southwest; Jos, Kaduna, Zaria, Kano, and Sokoto in the north; and a few other locations such as Benin, Owerri, Port-Harcourt (in the south) and Ilorin (middle belt). According to Ajayi, this spatial disparity in the distribution of manufacturing activities has often explained the reason for the dismal performance of the sector. He thus emphasize the need for the valorization of raw agricultural products or the treatment of raw materials for export, or through the principle of import substitution adopted by the Nigerian governments as their industrial planning strategy.

Alao (2010), using an error correction model observed that manufacturing sub-sector has been hindered by high interest rates, particularly the interest rate spread (IRS) which is the difference between lending and borrowing rates. It is also alleged that this rate is partly responsible for high cost of production in the Nigerian manufacturing sub-sector Adebiyi (2001), Adebiyi and Babatope-Obasa, 2004), and Babawale et al (1996)

Chimobi (2010) while estimating the relationship between Economic growth, Investment and Export in Nigeria observed that industrial production has the ability to increase investment which ultimately will lead to the production of more good, which eventually will yield growth in the domestic economy. Investment will lead to enhanced development in projects such as electricity supply, good road network, good medical care and host of other projects.

Despite the problems burdening the industrial sector in Nigeria, its contribution to GDP cannot be over emphasized. The industrial sector has been described as the engine that drives the economy of any nation. Diaz-Bautista (2003) empirical results indicate that industrial sector and overall economy are co-integrated and have a long run relationship in Mexico. The Granger causality test shows evidence that there exists a two way causal relationship between industrial growth and GNP thus supporting the findings that industrial output causes the overall economic growth for Mexico during the period under consideration.

Uddin and Norman (2002) examine the pattern of long run relationship between exports earnings and industrial activities in Bangladesh. The study applied Granger causality tests to find the direction of causality between exports and industrial production index. The results obtained revealed that there exists bi-directional causality between exports and industrial activities in Bangladesh. Thus, the authors summarized that a viable industrial sector was necessary to drive Bangladesh external trade.

Mamun and Nath (2005) had showed that though industrial production and export were co-integrated at the long run, there exists a uni-directional causality running from export to economic growth in Bangladesh. Kemal et al (2002) also found a positive association between export growth, industrial production and economic growth for India as well as other South Asian economies.

Ferda (2007) estimated a multivariate causality analysis of export and growth in turkey. Empirical evidence from the bounds co-integration test indicated that there existed only one long-run relationship between the variables in which real industrial production index is the dependent variable. Augmented Granger causality tests suggested that changes in real exports and terms of trade through the error correction term precede changes in real industrial index in the long-run. In the short-run, there is a uni-lateral causation running from changes in real exports to real industrial production index.

\section{Methodology}

The study shall utilize annual time series data from 1970 to 2006.All the data were obtained from the Central Bank of Nigeria statistical bulletin and Annual Report of various years. The study shall begin by testing the order of integration (i.e. the stationarity) of industrial production (RINDC) non-oil exports, (RNEXP) and Gross Domestic Product (RGNP). Two methods are used in practical application to test stationarity, Augmented Dickey-Fuller (ADF) test (Dickey and Fuller, 1981) and the non-parametric adjustment Phillip-Perron test (Phillip and Perron, 1988). It has 
been severally proven that time series data of economic variables are usually characterized by a unit root so that their first differences are stationary (Engel and Granger, 1987), Nelson and Ploser, (1982). Thus, given two time series that are integrated at order 1, i.e. I(1), then there must exist Granger causality in at least one direction in the I(0) variables (Engle and Granger, (1987). Therefore, after testing the stationary and co-integration attributes of the variables, the study shall further test for Granger causality with the error-correction model between industrial production, non-oil exports, and economic growth (in terms of GDP growth) of the country. Accordingly, the Augmented Dickey-Fuller test shall be specified as,

$$
\begin{gathered}
\Delta \mathrm{Y}_{\mathrm{t}}=\alpha 0+\alpha 1 \mathrm{Y} t-1+\sum_{\mathrm{t}-\mathrm{i}}^{\mathrm{n}} \alpha \Delta \mathrm{Y}_{\mathrm{t}}+\mathrm{e}_{\mathrm{t}} \\
\Delta \mathrm{Y}_{\mathrm{t}}=\alpha 0+\alpha 1 \mathrm{Y} t-1+\sum_{\mathrm{t}-\mathrm{i}}^{\mathrm{n}} \alpha \Delta \mathrm{Y}_{\mathrm{t}}+\partial_{\mathrm{t}}+\mathrm{e}_{\mathrm{t}}
\end{gathered}
$$

Where:

$\mathrm{Y}$ is a time series, $\mathrm{t}$ is a linear time trend, $\Delta$ is the first difference operator, $\alpha_{0}$ is a constant, $\mathbf{n}$ is the optimum number of lags in the dependent variable and $\mathbf{e}$ is the random error term. The Phillip-Perron (PP) equation is given as thus:

$$
\Delta \mathrm{Y}_{\mathrm{t}}=\alpha 0+\alpha 1 \mathrm{Y} t-1+\mathrm{e}_{\mathrm{t}}
$$

Where $\mathbf{e}_{\mathbf{t}}$ in the three equations are assumed to be identically independently distributed random variables,

The study shall further test for co-integration theory with the use of Johansen's Trace and Max-Eigen statistic estimation approach (Johansen, 1988; Johansen and Juselius, 1990, and Johansen, 1991).

The Augmented Engle-Granger test (Engle and Granger, 1987), and Phillip-Perron test (Phillip and Perron, (1988) are applied in testing order of integration of the co-integrating regression error term. Granger co-integration test would be applied to test the existence of a long-run relationship between the variables, which would be either uni-directional or feedback. The variables are said to be integrated if they exist in the order of 1(0) or 1(1).

If co-integration is proven to exist, then the third step requires the construction of error correction mechanism to model dynamic relationship. The purpose of the error correction model is to indicate the speed of adjustment from the short-run equilibrium to the long-run equilibrium state. The greater the co-efficient of the parameter, the higher the speed of adjustment of the model from the short-run to the long-run We represent equation (2) with an error correction form that allows for inclusion of long-run information thus, the Error Correction Model (ECM) can be formulated as follows:

$$
\Delta \log \operatorname{RINDC}_{\mathrm{t}}=\alpha 0+\sum_{\mathrm{t}-\mathrm{i}}^{\mathrm{n}} \alpha_{1 \mathrm{t}} \Delta \log \operatorname{RINDC}_{\mathrm{t}-1}+\sum_{\mathrm{t}-1}^{\mathrm{n}-1} \alpha_{1 \mathrm{t}} \Delta \operatorname{logRNEXP_{\mathrm {t}-1}}+\sum_{\mathrm{t}-1}^{\mathrm{n}-1} \alpha_{1 \mathrm{t}} \Delta \operatorname{logRGNP_{\mathrm {t}-1}}+\lambda \mathrm{Ec}_{\mathrm{t}-1}+\mu_{\mathrm{t}}
$$

Where $\Delta$ depicts the difference operator, $\lambda$ is the error-correction term obtained from the long-run co-integrating regression., RINDC, RNEXP and RNGDP are defined as logarithm for industrial Production, Non-oil Exports and Gross Domestic Product respectively. The Error Correction Model (ECM) method allows the distinction between 'short run' and 'long run' Granger causality. When variables are co-integrated in the short-run, the differences from the long-run equilibrium will feedback on the changes in the dependent variable so as to force the movement towards the long run equilibrium; if the dependent variable is caused directly by this long-run equilibrium error, then it is reacting to this feedback and if not, it is responding only to the short-run shocks to the stochastic environment. The short run adjustment coefficient, derived by estimating the coefficient of the lagged error correction term, represents the ratio by which the long run disequilibrium in the dependent variable is being corrected in each short-run period. The 'short run' causal effects are indicated through the significance of the F-tests of the 'differenced' independent variables whereas the significance of that t-test of the lagged error-correction term provides the long run causal relationship.

\section{Empirical Result}

\subsection{Stationarity Test}

The results of the unit root test indicate that at levels all the variables were not stationary, but on further differencing, they all became stationary at first difference. Therefore, the results confirm that all variables are integrated of order one 1(1) at first difference but were not integrated of order zero at levels, i.e. RGNP I(1), RINDC I(1), and REXP I(1). The result of Phillip-Perron stationarity tests are shown in table 2. The Phillip-Perron test confirms the result gotten from the $\mathrm{ADF}$ test. 


\subsection{Cointegration Test}

Table 3 shows the summary result of the Johansson's Maximum Likelihood co-integration test. The test relations were estimated with intercept and linear tend in Vector Auto Regression (VAR) model of order one (1) with a lag length of one (1), which was found to be most parsimonious for the data series. The $\lambda$-trace statistic rejects the null of $r \leq 0$ but cannot reject $r \geq 1$ and also, the $\lambda$-max statistic rejects the null of $r=0$ but fails to reject $r=1$ at $5 \%$ level. These Eigenvalue tests based on stochastic matrix indicate existence of the cointegrating relationship between industrial production and non-oil exports. So, the Granger causality tests will be modeled using ECM as explained in Equations (4) to (6).

\subsection{Granger Causality Test}

The result of the Granger causality test presented in table 4 suggests that there exist a uni-directional causality that runs from industrial production to non-oil exports. The result also indicates that industrial production also granger causes real growth in domestic product, with the causality running from industrial production to real GDP. The result brings out the proposition that industrial production is a pivot to promoting growth in non-oil export which ultimately leads to an expansion of the country's GDP. Thus factors that impinge on the performance of the industrial sector will ultimately lead to either improvement or depreciation in the country's Gross Domestic production.

\subsection{Error Correction Test}

The coefficient of the error-correction terms in the study carries the correct sign and it is statistically significant at 5 percent, with the speed of convergence to equilibrium (which is often referred to as the ECM) at 45.9 per cent (see Table 5). In the short run, industrial firms adjust production by 45.9 percent of the past deviation from equilibrium. The value of error-correction term is rather moderate; therefore, restoration to equilibrium level in the real industrial production index in event of deviation is expected to be moderately fast. As for the short-run, the F-statistics on the explanatory variables demonstrate that there is uni-directional Granger causality between non-oil exports. Nevertheless, the strength of this causation is rather weak as far as the F-statistic is concerned.

The co-integration result reveals that a 100 percent rise in industrial production in one lag period in the short run will lead to 76 percent rise in non-oil export production and a 7 percent rise in GDP in the current period. The result further predicts that in the long run, industrial production is expected to reduce by 97 percent, while non-oil export contribution to GDP will be estimated at only 1 percent if the current industrial production trend continues. This is particularly so true given the current problems bedeviling the industrial sector in Nigeria. It is significant in this study to note that the industrial sector drives non-oil exports. A sound and vibrant industrial sector has the ability not only to promote non-oil export growth, but improve the balance of payment position of the country through export earnings.

\section{Policy Implications and Conclusion}

The aim of this paper is to identify the role of the industrial sector plays in driving the country's GDP. The paper was also to predict the long-run behavioral relationship between non-oil exports and economic growth in Nigeria using data from 1970 - 2006. The Vector Error Correction approach of co-integration has been applied to Granger test the causality between industrial production, non-oil exports and economic growth. The unit root test reveals that all the variables were stationary at first difference. These results further supported a stable long run relationship between non-oil exports and industrial production, and thus, yield evidence of a single co-integrating vector.

Furthermore, a significant and positive uni-directional Granger causal relationship exists between industrial production and non-oil exports in Nigeria. These results attest to the fact that industrial production is a pivot to promoting non-oil export in Nigeria, with a resultant trickle down effect of increasing Economic growth. The study remarkably revealed that the current production pattern among Nigerian industries does not favor non-oil export in the current period. The result in this study support the accession that the industrial sector in Nigeria had suffered from (a) The unfavorable tax regimes, (b) Socio-Economic disparities and ethnic divides frequently accompanied by militants attacks on manufacturing infrastructures, particularly, at the Niger delta region of Nigeria, (c) armed extremisms and religious intolerance, (d) Weal linkage between manufactures products and foreign markets in terms of both inputs and delivery, (e) infrastructure deficit, especially in power, road network and storage systems, and (f) weak administrative policies that often lead to polarization of industries to particular region of the country. The study therefore conclude that, the industrial sector in Nigeria might suffer severe collapse in the long-run if remedial measures are not quickly undertaken to strengthen the ailing industries.

It is recommended in this study that the following remedial measures be taken to revamp the industrial sector in other to boost non-oil production in Nigeria, 
1. The electricity situation in the country need to be improved upon as a matter of urgency since most industries in Nigeria depends heavily on the usage of private generators to power their production. This action of course increases the over head cost of production.

2. Wide interest rate has been severally observed as the factor affecting accessibility of firms to loans by entrepreneurs. Thus, the monetary authorities need to intensify effort at pursuing financial reforms targeted at reducing high interest. A moderate interest rate will act to stimulate the market for non-oil produce.

3. In other to encourage local entrepreneurs to increase their production, the government needs to restore the 25 percent import duty rebates for industrial raw materials, machineries and spare parts. The high cost of purchasing these materials constitutes a huge over head cost on the industries.

4. The Federal Government should strengthen and revise the credit guarantee scheme. Legal and supervisory framework should be reinforced to track the use of these funds as well as identified loan defaulters. Perceive delays and bottlenecks in the disbursement of fund should also be identified and removed to ensure prompt release and application of funds.

5. The proposed bail out plan of 200 billion by federal government to manufacturing industries should be expedited.

6. Relevant agencies over seeing the industrial sector should institute mechanism that will ensure good corporate governance among managing directors in the industry.

7. The establishment of Microfinance Banks (former Community Banks), Small and Medium Industries Equity Investment Scheme (SMIEIS), Small and Medium Enterprises Development Agencies of Nigeria (SMEDAN), Bank of Industry (BOI) should be overhauled for development and improvement in the local production.

8. Central Bank of Nigeria through Bankers Committee should ensure that the disbursement of the SMIEIS' fund for manufacturing firms and industries are not diverted to private purses.

It is expected that non-oil exports should boost gross domestic growth through foreign exchange earnings. The industrial sector therefore, has been identified as necessary engine that would stimulate growth in non-oil production for export. Given the poor performance of the industrial sector in Nigeria, it is therefore expedient that the government create an enabling environment that will ensure the survival and functioning of the ailing industries.

\section{References}

Adebiyi, A. (2001). Trade Liberalisation Policy and Industrial Growth Performance in Nigeria: An Error Correction Mechanism. (ECM) Technique. (Online) Available www.bayoadebiyi.com/Adebiyi Michael Adebayo/trade liberalization policy and industrial growth performance in Nigeria.

Adejugbe, M.O.A. (1980). Nigeria's industrial Policies and performance in the Military Era, 1966-1979. Proceedings of the annual Conference of the Nigeria Economic Society

Adejugbe, M.O.A. (1997) Stimulating Non-oil Sector through Marketing and Trading Strategies. Central Bank of Nigeria Economic and Financial Review, Vol 35.(4)22-26.

Adeniran, O. (2008) Does Energy Consumption cause Economic Growth? An Empirical Evidence from Nigeria. (Online) Available www.dundee.ac.uk/cepmlp/gateway/files.php?

Ahmed, J., \& Harnhinen, S. (1995). Unit roots and co-integration in Estimating Causality between Exports and Economic growth: Empirical Evidence from The ASEAN countries, Economic Letters, 49.

Ajayi, Dare Dickson. (2007). Recent Trends and Patterns in Nigeria's Industrial Development. Africa Development, Vol. XXXII, No. 2.

Alao, R.O. (2010). Productivity in the Nigerian Manufacturing Sub-Sector: An Error Correction Model. (ECM). European Journal of Economics, Finance and Administrative Sciences, Issue 20, 25-33.

Awoseyila, A.P. (1997). Appraisal of past and Present Policy Measures for Reviewing Nigeria's Non-oil Sector and Policy Implications for the future. Central Bank of Nigeria Economic and Financial Review, Vol 35. (4).

Babawale, T. A. et al. (1996). Nigeria Beyond Structural Adjustment: Towards a National Popular Alternative Development Strategy. Africa Development, Vol. XXI, Nos. $2 \& 3$.

Balogun, E.D. (1997). Towards Efficient Institutional Arrangements for Non-oil Sector Development in Nigeria Central Bank of Nigeria Economic and Financial Review, Vol 35. No 4.

Chimobi, O.P. (2010). The Estimation of Long-run Relationship between Economic Growth, Investment and Export in Nigeria. International Journal of Business and Management, Vol. 5,(4) 215-2191. 
Díaz-Bautista, A. (2004). Mexico's Industrial Engine of Growth: Cointegration and Causality. (Online) Available www. ideas.repec.org/p/wpa/wuwpem/0402010.html

Dickey, D.A., \& Fuller, W.A. (1979). Distributions of the Estimators for Autoregressive Time Series with a Unit root. Journal of the American Statistical Association, 74.

Enang,B.U. (2010). Industrial Development, Electricity Crisis and Economic Performance in Nigeria. European Journal of Economics, Finance and Administrative Sciences, Issue 18.

Engel, R.F., \& Granger, C. W. (1987). Co-integration and Error Correction Representation, Estimation and Testing Econometrica, Vol.55. (2) 251-76. http://dx.doi.org/10.2307/1913236

Feder, H. (2007). A Multivariate Causality Analysis of Export and Growth for Turkey, MPRA Paper No. 3565.

Ikpeze, N, Soludo, C.C., \& Elekwa, N.N. (2001). Nigeria: The Political Economy of the Policy Process, policy Choice and Implementation, Industrial policy in Africa-Forced Consensus. Chapter 13.

Johanson, Soren. (1989). Statiscal Analysis of Co-integration Vectors, Journal of Economic Dynamics and Control Vol 12

Johansen, S., \& Juselius, K. (1990). Maximum Likelihood Estimation and Inference on Co-integration- with Applications to the Demand for Money, Oxford Bulletin of Economics and Statistics, 52,

Kemal, A. R., Din, M., Qadir, U., Fernando, L., \& Colombage, S. (2002). Exports and Economic Growth in South Asia A Study prepared for the South Asia Network of Economic Research Institutes.

Mamun, K., Al, A., \& Nath, H.K. (2005). Export-led growth in Bangladesh: a time series analysis. Applied Economics Letters, Vol.12, Issues 6

Nelson, C.F., \& Plosser, C.I. (1982). Trends and Random walks in Macroeconomic Time-series-some Evidence and implications. Journal of Monetary Economics, 10

Onyeonoru, I. (2003). Globalization and Industrial Performance in Nigeria. Africa Development, Vol. XXVIII, Nos. 3 $\& 4$,

Pesaran, M.H., Shin, Y., \& Smith, R.J. (2001). Bounds testing approaches to the analysis of level relationships Journal of Applied Econometrics, 16.

Phillips, P.C., \& Perron, P. (1988) Testing for a unit root in a time series regression, Biometrica, 75.

Soludo, C.C. (1998). Africa: Industrialisation Strategy in the context of Globalization in Iqbal and M. khan. (Eds) Trade Reforms and Regional Integration in Africa, Washington, DC. IMF

Uddin, M.G.S., \& Norman, A.M. (2009). Causality between Industrial Production and Exports in Bangladesh.. (Online) Available www.gbmf.info/2009/Causality_Gazi_salah_uddin.pdf.

Ukpong, G.E. (1997). Production Trend of Selected Non-oil Products in Nigeria. Central Bank of Nigeria Economic and Financial Review, Vol 35. (4).

Table 1. Augmented Dickey- Fuller Test for Unit root

\begin{tabular}{|l|l|l|l|l|}
\hline Variables & Critical & Level & First Difference & Order of Integration \\
\hline RINDC & -2.945842 & -0.383120 & -7.045124 & $1(1)$ \\
\hline RGNP & -2.954021 & 0.804235 & -5.312427 & $1(1)$ \\
\hline RNEXP & -2.945842 & -0.665101 & -6.742550 & $1(1)$ \\
\hline
\end{tabular}

Note: The 5\% critical value for the ADF Statistic approximately -2.945842 for levels and -6.742550 for first difference. These critical values are computed from McKinnon(1996).

Table 2. Phillips - Perron Test for Unit root

\begin{tabular}{|l|l|l|l|l|}
\hline Variables & Critical & Level & First Difference & Order of Integration \\
\hline RINDC & -2.945842 & 0.458472 & -8.628072 & $1(1)$ \\
\hline RGNP & -2.945842 & 0.232312 & -9.878764 & $1(1)$ \\
\hline RNEXP & -2.945842 & -0.253445 & -7.238242 & $1(1)$ \\
\hline
\end{tabular}

Note: The $5 \%$ critical value for the ADF Statistic approximately -2.945842 for levels and -8.62807 for first difference. These critical values are computed from McKinnon(1996). 
Table 3. Results of Johansen's Co-integration Test

\begin{tabular}{|c|c|c|c|c|c|}
\hline \multicolumn{2}{|c|}{ Hypothesis } & \multicolumn{2}{|c|}{ Maximum Eigenvalue } & \multicolumn{2}{|c|}{ Trace test statistic } \\
\hline Null & Alternative & Statistic & Critical value at $5 \%$ & Statistic & Critical value at $5 \%$ \\
\hline $\mathrm{r}=\mathrm{o}$ & $\mathrm{r}=1$ & 23.6880 & $20.97 * *$ & 41.5940 & 29.68 \\
\hline $\mathrm{r} \leq 1$ & $r=2$ & 13.6127 & $7.264 *$ & 13.6127 & 8.29 \\
\hline$r \leq 1$ & $\mathrm{r}=3$ & 2.1670 & 3.76 & 2.1670 & 3.76 \\
\hline
\end{tabular}

$*(* *)$ denotes rejection of the hypothesis at the $5 \%(1 \%)$ level

Table 4. Granger Causality Test

\begin{tabular}{|lccc|}
\hline Null Hypothesis: & Obs & F-Statistic & Probability \\
\hline RINDC does not Granger Cause RGNP & 35 & 4.50111 & $0.03915^{*}$ \\
\hline RGNP does not Granger Cause RINDC & & 0.43588 & 0.65073 \\
\hline RNEXP does not Granger Cause RGNP & 35 & 0.45119 & 0.64112 \\
\hline RGNP does not Granger Cause RNEXP & & 3.25606 & $0.05251^{*}$ \\
\hline RNEXP does not Granger Cause RINDC & 35 & 0.58442 & 0.56365 \\
\hline RINDC does not Granger Cause RNEXP & & 4.46016 & $0.03248^{*}$ \\
\hline
\end{tabular}

*Denotes significance at $5 \%$ level

Table 5. Short run and Long run VECM estimates

\section{Long-run estimate}

\begin{tabular}{|l|l|l|l|}
\hline Regressors & Long run estimate & Standard error & t-values \\
\hline RGNP(-1) & 1.000 & & \\
\hline RINDC(-1) & -0.979399 & 0.07532 & -13.0038 \\
\hline RNEXP(-1) & 0.019479 & 0.08623 & 0.22589 \\
\hline Constant & -1.389919 & & \\
\hline
\end{tabular}

\section{Short-run estimates}

\begin{tabular}{|c|c|c|c|}
\hline Error Correction: & $\mathrm{D}($ RGNP) & $\mathrm{D}($ RINDC) & $\mathrm{D}$ (RNEXP) \\
\hline CointEq1 & -0.459799 & 1.021105 & 1.259034 \\
\hline & $(0.73169)$ & $(0.67246)$ & $(0.77890)$ \\
\hline $\mathrm{D}(\mathrm{RGNP}(-1))$ & -0.448851 & -0.745659 & -0.763178 \\
\hline $\mathrm{D}(\mathrm{RINDC}(-1))$ & $(0.54146)$ & $(0.49763)$ & $(0.57639)$ \\
\hline $\mathrm{D}(\mathrm{RNEXP}(-1))$ & 0.073995 & 0.695443 & 0.767936 \\
\hline $\mathrm{C}$ & $(0.65667)$ & $(0.60351)$ & $(0.69904)$ \\
\hline & 0.027298 & -0.243754 & -0.261290 \\
\hline & 0.367255 & 0.348092 & 0.254564 \\
\hline
\end{tabular}

$\mathrm{R}^{2}=0.3194$, Adj $\mathrm{R}^{2}=0.1361, \mathrm{~F}-$ Statistics $=11.7431$, 